\title{
Effect of different protein levels of fry feed on the production of quality tilapia (Oreochromis niloticus) fry
}

\author{
K. R. Sumi, M. Das and I. Siddika \\ Department of Aquaculture, Bangladesh Agricultural University, Mymensingh-2202, Bangladesh \\ Email: sumi.02bau@gmail.com
}

\begin{abstract}
A 4-week long feeding experiment was conducted to evaluate the effect of different protein levels of quality Tilapia $(O$. niloticus) fry production in Agro-3 Fish Hatchery and Culture Farm, Boilor, Trishal, Mymensingh. Four days old 1247 fry (length $0.8 \mathrm{~cm}$ and weight $0.012 \mathrm{~g}$ ) were stocked at the density of $1560 / \mathrm{m}^{2}$ in twelve synthetic hapas. Four different treatments $\left(T_{1}, T_{2}, T_{3}\right.$ and $\left.T_{4}\right)$ in three replications were used having different level of protein containing diets ( $T_{1}=35.95 \%, T_{2}=40.43 \%, T_{3}=45.61 \%$ and $\left.T_{4}=50.85 \%\right)$ in the experiment. Feeds were supplied to fry at $4 \mathrm{~h}$ intervals during $24 \mathrm{~h}$ cycle upto satiation level. Sampling was done at 7 days interval throughout the experiment. The best growth was obtained at $35.95 \%$ protein level in $\mathrm{T}_{1}$ treatment. Therefore, a follow up second experiment with feeds having protein levels $30.12 \%, 33.42 \%, 36.19 \%$ and $39.01 \%$ encircling the best performed diet (35.95\% protein) of the first experiment was conducted. Significantly $(P<0.05)$ higher mean weight gain $(\mathrm{g})$, SGR $(\% /$ day), PER, survival rate (\%) and lower FCR value were found at $36.19 \%$ protein containing diet. Thus, from the results of the two experiments conducted in two consecutive years it can be said that the feed containing approximately $36 \%$ protein is the best for the production of quality tilapia fry. If farmers use $36 \%$ protein instead of $40 \%$ then it will be more economic because fish meal is costly. Further experiment can be carried with feed containing $36 \%$ protein from cheaper ingredients other than fish meal to reduce the feed cost.
\end{abstract}

Keywords: Tilapia fry, Protein levels of diets, Growth performance

\section{Introduction}

Nile Tilapia has been introduced in our country because of its high market demand and growth performance. It can be cultured in almost any type of water bodies. It grows to marketable size within short period of time and its survivality is also very high. Tilapia reproduces easily, accepts wide variety of food and can tolerate poor water quality with low dissolved oxygen levels and is also disease-resistant.

The nutritional requirements of tilapia are very similar to other warm water fishes (Popma and Lovshin, 1995). The diet of fishes must be balanced and should contain the primary or basic food components such as proteins, carbohydrates and lipids. Protein is the most expensive macronutrient in fish diet. The dietary protein requirement for fish fry is high and ranges from $35 \%$ to $56 \%$ (Jauncy and Ross, 1982). Furthermore, dietary protein requirements decreased with increasing fish size and age (Wilson, 1989, Pillay, 1990 and El-Sayed and Teshima, 1991). Based on various studies a general conclusion is made that fry of tilapia of size $<1 \mathrm{~g}$ requires diet with $35-50 \%$ protein, $1-5 \mathrm{~g}$ fish requires diet with $30-40 \%$ protein and 5-25 g fish requires diet with $25-35 \%$ protein (Balarin and Haller, 1982).

In recent years tilapia culture has grown rapidly in Bangladesh. In response to the expansion of tilapia aquaculture, considerable attention has also been given to ensure a continuous supply of high quality tilapia seed. At present, to meet the demand for tilapia fingerlings more than 250 tilapia hatcheries has been established and are producing 3000 million fry every year in Bangladesh (Hussain et. al., 2011).

In Tilapia culture, fry feed is very important because the quality of Tilapia fry depends on the quality of fry feed. Fry feeds generally contain higher level of protein because it is believed that the protein and energy requirements on a unit mass basis are much higher in the early stages of life. The highest relative weight gain is achieved in the fry stages and it is important to ensure that full growth potential is realized during this stage of development. The protein content of fry feed in our tilapia farms have not yet been standardized although some farms use feed having $40 \%$ protein. The survival of fry in the farm is also low by feeding feeds of differential protein levels in different farms. So it is essential to recommend the appropriate protein level of fry feed for economic production of healthy fry and to maximize survivality as well. So, the present study was undertaken to conduct experiment with different protein level diets viz $35 \%, 40 \%, 45 \%$, and $50 \%$ protein of fry feed to determine growth performance and survival rate of tilapia fry at different protein levels. 


\section{Materials and Methods}

An experiment was conducted in a selected private farm called Agro-3 "Fish Hatchery and Culture Farm" located at Boilor under Trishal upazila in Mymensingh district for production of quality Tilapia (O. niloticus) fry for a period of 28 days from $25^{\text {th }}$ August to $22^{\text {nd }}$ September, 2010. Twelve same size hapas $(0.81 \mathrm{~m} \times$ $0.96 \mathrm{~m} \times 1.02 \mathrm{~m}$ ) were washed using bleaching powder and set into the pond by using bamboo sticks. Fertilized eggs were collected manually from the mouth of tilapia brood fish previously stocked in hapa set into brood pond in the farms. The fertilized eggs were transferred to hatching trays for hatching. After hatching yolk sac gradually absorbed in 4 days. Then the fry $(0.012 \mathrm{~g})$ were stocked in experimental hapa. At first feeds were formulated containing $35 \%, 40 \%, 45 \%$ and $50 \%$ protein from three ingredients such as fish meal, rice bran and wheat flour supplied by the farm owner. Formulation of feeds was done by Pearson's method. After formulation, feeds were prepared by mixing ingredients and proximate analysis was done. The protein levels of the prepared feeds were found $35.95 \%, 40.43 \%, 45.61 \%$ and $50.85 \%$ (Table 1, Section A). All the prepared feeds were stored separately in air-tight polythene bags in the refrigerator for use during experimental period. Proximate compositions of prepared feeds were analyzed following the standard methods given by Association of Official Analytical Chemists (AOAC, 2000) at the Fish Nutrition Lab in the Department of Aquaculture, Faculty of Fisheries.

The experiment was designed into 4 treatment groups (group $T_{1}, T_{2}, T_{3}$ and $T_{4}$ ) fed with diet of different $(35.95 \%, 40.43 \%, 45.61 \%$ and $50.85 \%)$ protein levels. Four (4) days old 1247 fry of initial average length $0.8 \mathrm{~cm}$ and weight $0.012 \mathrm{~g}$ were released at the same stocking density $\left(1560 / \mathrm{m}^{2}\right)$ in each hapa on $25^{\text {th }}$ August, 2010. For each protein level three replications were used and fries were fed $4 \mathrm{~h}$ intervals during $24 \mathrm{~h}$ cycle.

The water quality parameters of different hapas were measured at fortnightly interval throughout the experimental period. The parameters like dissolved oxygen and $\mathrm{pH}$ were determined by respective test kits and temperature by Celsius/ centigrade thermometer.

Weekly sampling of fry were done by a scoop net and kept in a bowl with water. Weight was recorded by using a digital balance (AND GULF, Dubai, U.A.E, model: GL-300) and growth performances were calculated.

$$
\begin{aligned}
& >\quad \text { Weight gain }(\mathrm{g})=\text { Mean final weight }- \text { Mean initial weight } \\
& >\quad \text { Specific growth rate }(\% / \text { day })=\frac{\left(\log _{e} W_{2}-\log _{e} W_{1}\right)}{\left(T_{2}-T_{1}\right)} \times 100(\text { Brown, 1957) } \\
& \text { Where, } W_{2}=\text { Final live body weight ( } g \text { ) at time } T_{2} \\
& \mathrm{~W}_{1}=\text { Initial live body weight }(\mathrm{g}) \text { at time } \mathrm{T}_{1} \\
& >\quad \text { Food conversion ratio }(\mathrm{FCR})=\frac{\text { Feed fed }(\text { dry weight })}{\text { Live weight gain }(\mathrm{g})} \\
& >\quad \text { Protein efficiency ratio }(\mathrm{PER})=\frac{\text { Live weight gain }(\mathrm{g})}{\text { Crude protein fed }(\mathrm{g})} \\
& >\quad \text { Survival rate }(\%)=\frac{\text { Total number of fish harvested }}{\text { Total number of fish stocked }} \times 100
\end{aligned}
$$

The best growth was performed by $35.95 \%$ protein level diet which was the lowest value of the treatment series. Therefore, a follow up second experiment with feeds having protein levels both higher and lower than the best performed diet of the first experiment (containing 35.95\% protein) viz. $30.12 \%, 33.42 \%$, $36.19 \%$ and $39.01 \%$ (Table 1, Section B) was conducted. The experiment was conducted for a period of 28 days from $22^{\text {nd }}$ June to $20^{\text {th }}$ July, 2011 following the same protocols of the first experiment. 
Table 1. Proximate chemical composition of different feeds containing different protein levels

\begin{tabular}{|c|c|c|c|c|c|c|}
\hline \multicolumn{7}{|c|}{ A Experiment 1} \\
\hline $\begin{array}{c}\text { Feeds with } \\
\text { different protein } \\
\text { levels }\end{array}$ & $\begin{array}{c}\% \\
\text { Moisture }\end{array}$ & $\begin{array}{c}\% \\
\text { lipid }\end{array}$ & $\begin{array}{c}\% \\
\text { Crude protein }\end{array}$ & $\begin{array}{c}\% \\
\text { Ash }\end{array}$ & $\begin{array}{c}\% \\
\text { Crude fibre }\end{array}$ & $\begin{array}{c}\% \\
\text { Carbohydrate }\end{array}$ \\
\hline 35\%protein & 12.36 & 12.70 & 35.95 & 11.54 & 5.25 & 22.20 \\
\hline $40 \%$ protein & 12.69 & 11.94 & 40.43 & 13.42 & 5.25 & 16.27 \\
\hline 45\%protein & 13.06 & 10.17 & 45.61 & 13.77 & 5.66 & 11.73 \\
\hline $50 \%$ protein & 12.57 & 10.09 & 50.85 & 12.26 & 5.40 & 8.83 \\
\hline \multicolumn{7}{|c|}{ B Experiment 2} \\
\hline 29\%protein & 12.55 & 11.25 & 30.12 & 7.91 & 5.20 & 32.97 \\
\hline $32 \%$ protein & 13.35 & 12.11 & 33.42 & 8.49 & 5.65 & 26.98 \\
\hline 35\%protein & 13.40 & 12.25 & 36.19 & 8.83 & 5.85 & 23.48 \\
\hline 38\%protein & 13.86 & 12.45 & 39.01 & 9.42 & 5.92 & 19.34 \\
\hline
\end{tabular}

For both the experiments, the collected data were statistically analyzed by one way ANOVA (Analysis of Variance) to see whether there are differences in different treatments. The means of different parameters were compared by Duncan's new multiple range test (DMRT) at 5\% probability level (Zar, 2010).

\section{Results and Discussion}

The water temperature monitored during the study period in the experimental hapas was 26.5 to $32^{\circ} \mathrm{C}$ i.e. within the suitable range. Similar findings were reported by Boyd (1982), Hossain et al. (2004). The dissolved oxygen content in the present experiment ranged from 6 to $6.5 \mathrm{mg} / \mathrm{l}$ that is suitable for tilapia culture as described by Rahman (1992) and DoF (1996). During the study period the pH value was also within the suitable range of 7.5 to 8.3 (DoF, 1996). The water quality parameters are presented in Table 2.

Table 2. Water quality parameters observed during both the experimental period

\begin{tabular}{|l|c|}
\hline Parameters & Value range \\
\hline Temperature $\left({ }^{\circ} \mathrm{C}\right)$ & $26.5-32$ \\
\hline $\mathrm{DO}(\mathrm{mg} / \mathrm{l})$ & $6-6.50$ \\
\hline $\mathrm{pH}$ & $7.5-8.3$ \\
\hline
\end{tabular}

The growth performance of tilapia fry in terms of initial weight $(\mathrm{g})$, mean final weight $(\mathrm{g})$, mean weight gain (g), specific growth rate (\%/day) were calculated at the end of the experiment. The initial average weight of fry in different treatments was $0.012 \mathrm{~g}$. Mean weight $(\mathrm{g})$ of tilapia fry at 7 days interval in first and second experiments is presented in Fig. 1 and Fig. 2 respectively. The final weight of fry was within 0.10 to $0.22 \mathrm{~g}$ in different treatments of the experiment 1 and 0.14 to $0.22 \mathrm{~g}$ in the second experiments. Highest final weight (0.22) was recorded in the diet containing $35.95 \%$ and $36.19 \%$ protein in the first and second experiment respectively and value was significantly higher than other treatments in both the experiments. Similarly the significantly $(P<0.05)$ highest mean weight gain $(\mathrm{g})$ was observed in $\mathrm{T}_{1}$ (35.95\% protein containing diet) and $\mathrm{T}_{3}(36.19 \%$ protein containing diet) in the first and second experiment respectively (Fig. 3 and 4).

The specific growth rate of fry under different treatments was within 7.55 to10.28\%/day in experiment 1 and 9.05 to $11.06 \% / d a y$ in experiment 2 . The significantly $(P<0.05)$ highest SGR was found in treatment $T_{1}$ and $T_{3}$ of the first and second experiment respectively (Fig. 5 and 6). Santiago et al. (1982) reported that the optimum dietary crude protein level for $O$. niloticus fry was 35 to $40 \%$.

The food conversion ratio in different treatments ranged from 2.35 to 5.81 in experiment 1 and 2.30 to 3.87 in experiment 2. The best (lowest) FCR (2.35 and 2.30) was observed in treatment $T_{1}$ and $T_{3}$ i.e. diet containing $36 \%$ protein of the first and second experiment respectively (Fig. 7 and 8). Best FCR was obtained by Bahnasawy (2009) feeding 35\% protein diet in Tilapia (O. niloticus) fry. 


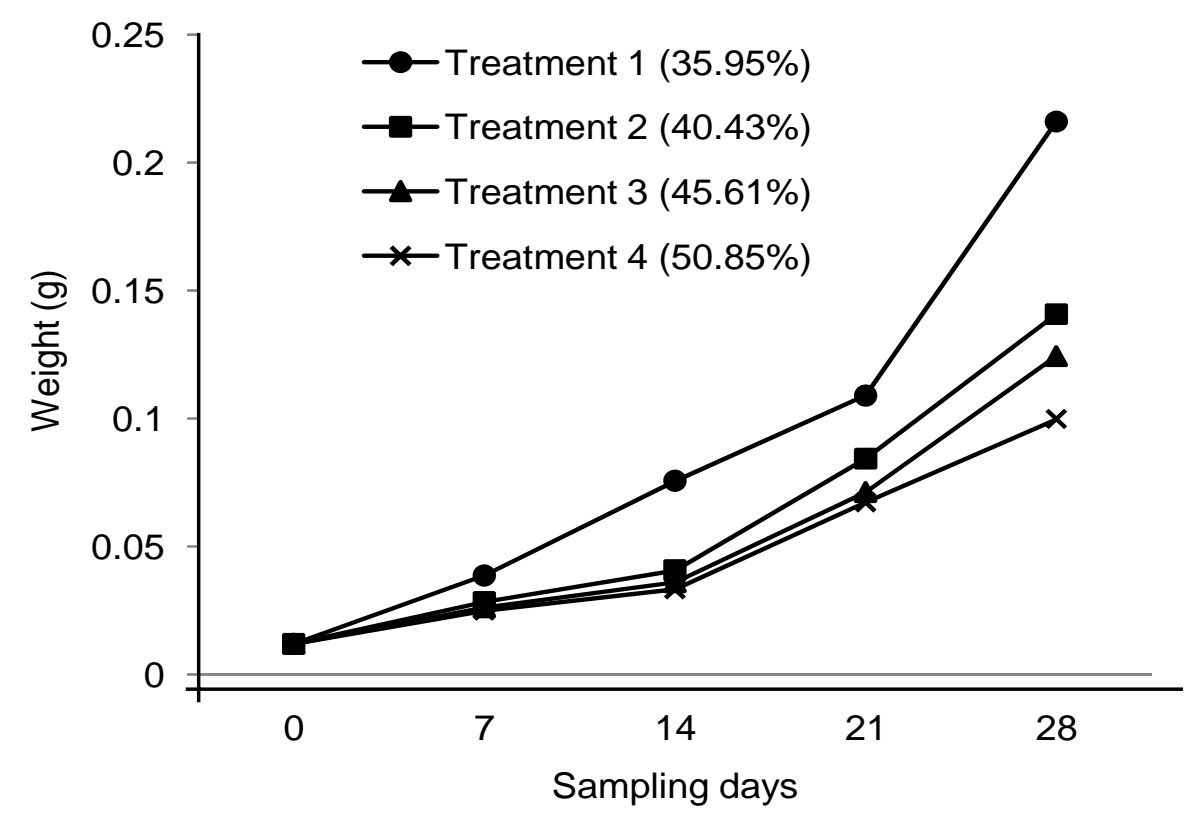

Fig. 1. Comparison of mean weight (g) of $O$. niloticus fry fed different protein containing diets at 7 days interval during the first experiment.

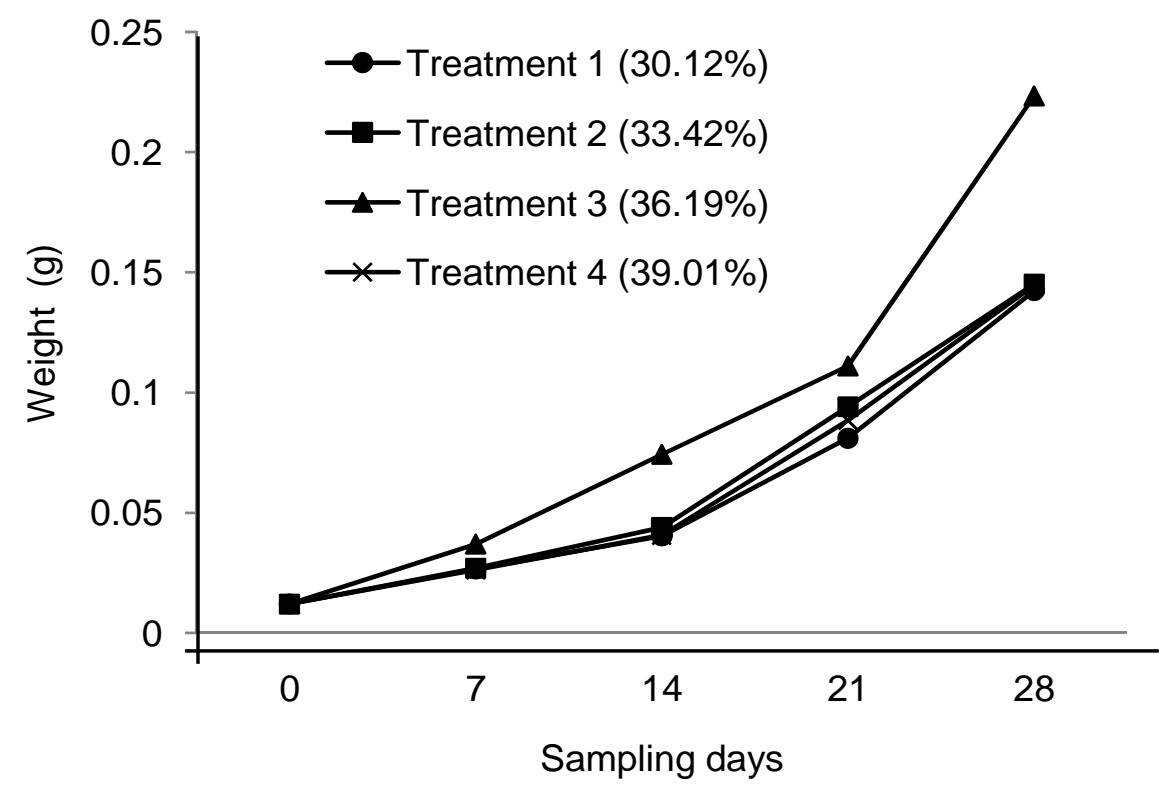

Fig. 2. Comparison of mean weight ( $\mathrm{g}$ ) of $O$. niloticus fry fed different protein containing diets at 7 days interval during the second experiment. 


\section{Sumi et al.}

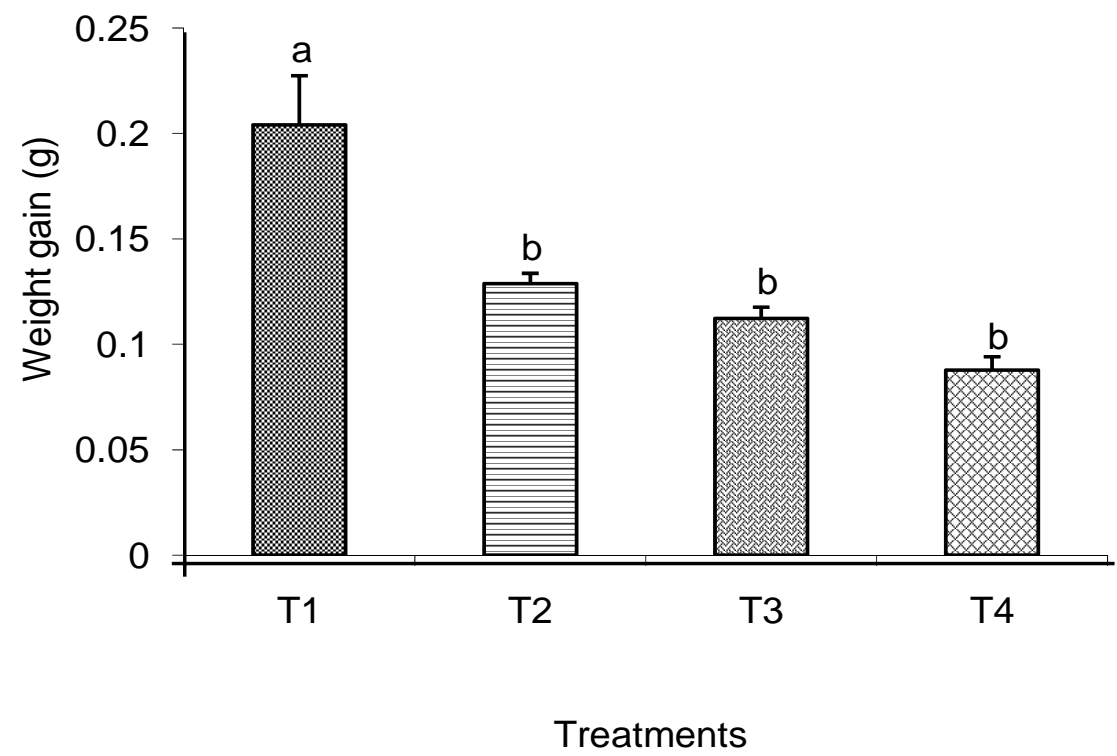

Fig. 3. Comparison of mean weight gain of $O$. niloticus fry fed different protein containing diets during the first experiment where $\mathrm{T}_{1}=35.95 \%, \mathrm{~T}_{2}=40.43 \%, \mathrm{~T}_{3}=45.61 \%$ and $\mathrm{T}_{4}=50.85 \%$.

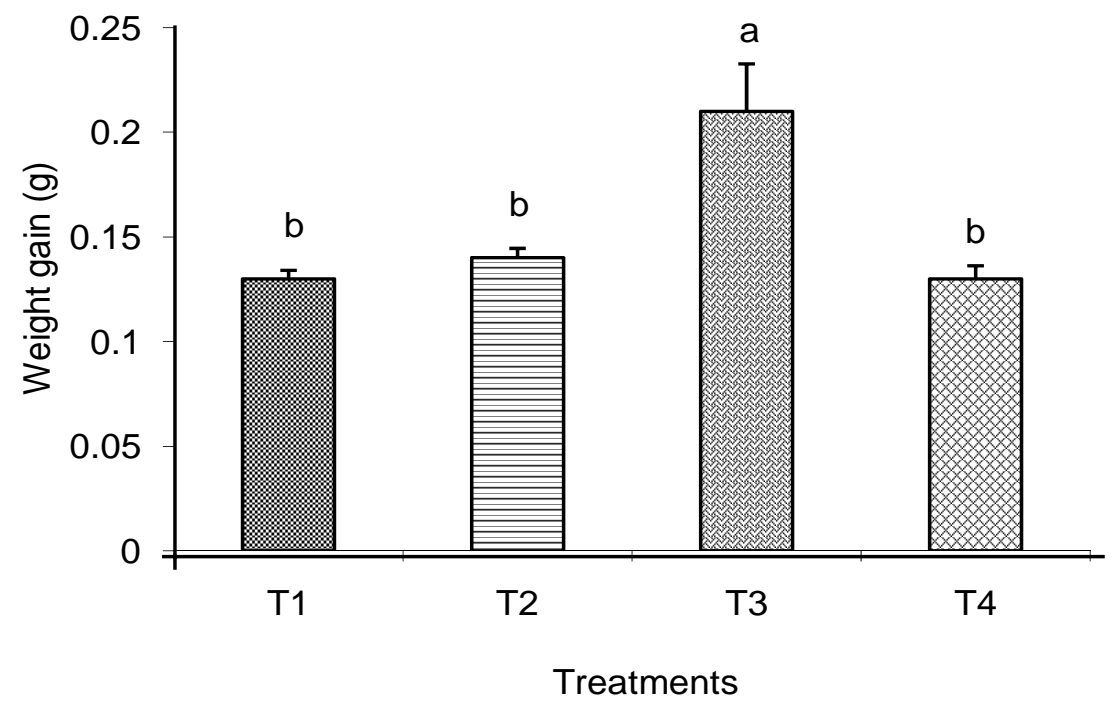

Fig. 4. Comparison of weight gain $(\mathrm{g})$ of $O$. niloticus fry fed different protein containing diets during the second experiment where $\mathrm{T}_{1}=30.12 \%, \mathrm{~T}_{2}=33.42 \%, \mathrm{~T}_{3}=36.19 \%$ and $\mathrm{T}_{4}=39.01 \%$. 


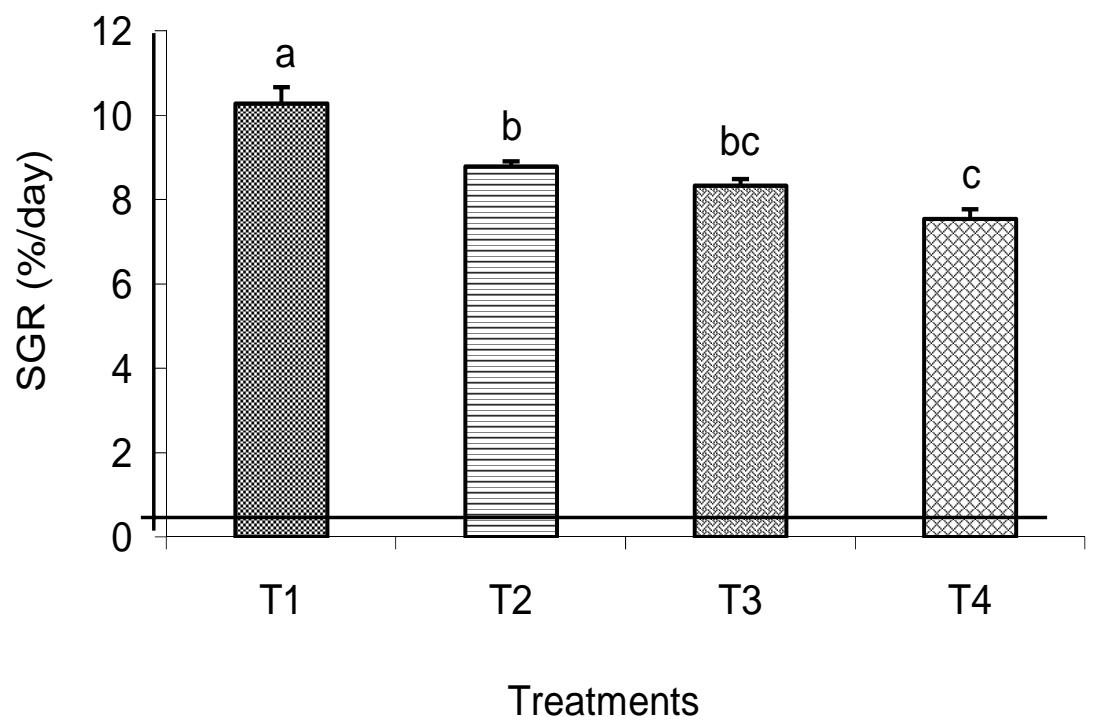

Fig. 5. Comparison of mean specific growth rate (\%/day) of $O$. niloticus fry fed different protein containing diets during the first experiment where $\mathrm{T}_{1}=35.95 \%, \mathrm{~T}_{2}=40.43 \%, \mathrm{~T}_{3}=45.61 \%$ and $\mathrm{T}_{4}=50.85 \%$

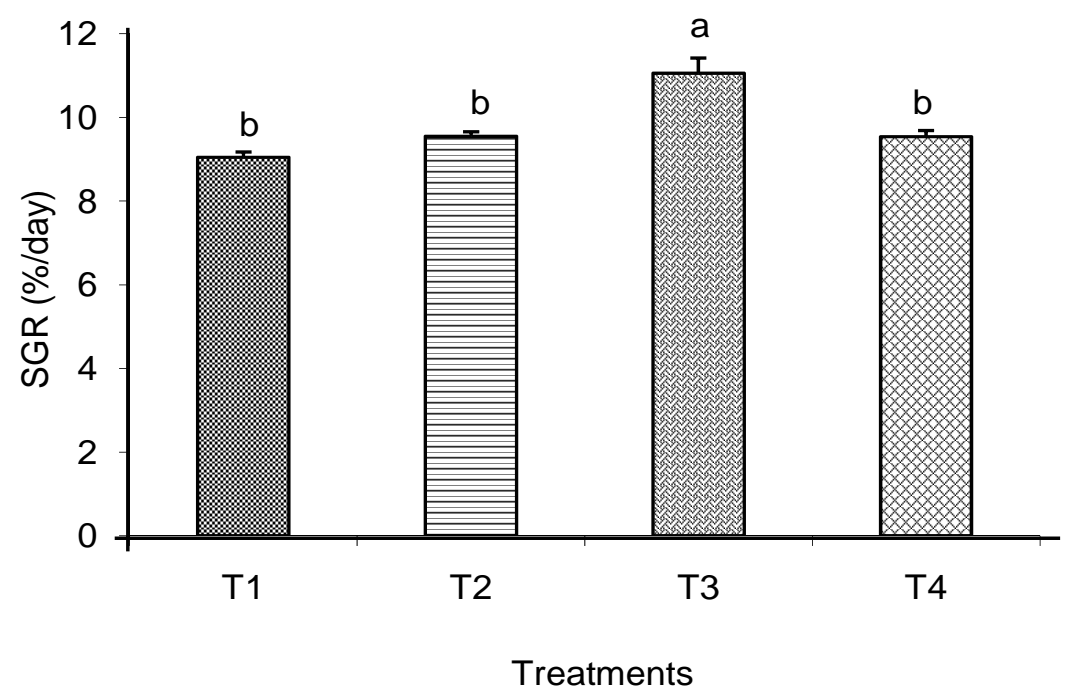

Fig. 6. Comparison of specific growth rate (SGR) of O. niloticus fry fed different protein containing diets during the second experiment where $\mathrm{T}_{1}=30.12 \%, \mathrm{~T}_{2}=33.42 \%, \mathrm{~T}_{3}=36.19 \%$ and $\mathrm{T}_{4}=39.01 \%$ 


\section{Sumi et al.}

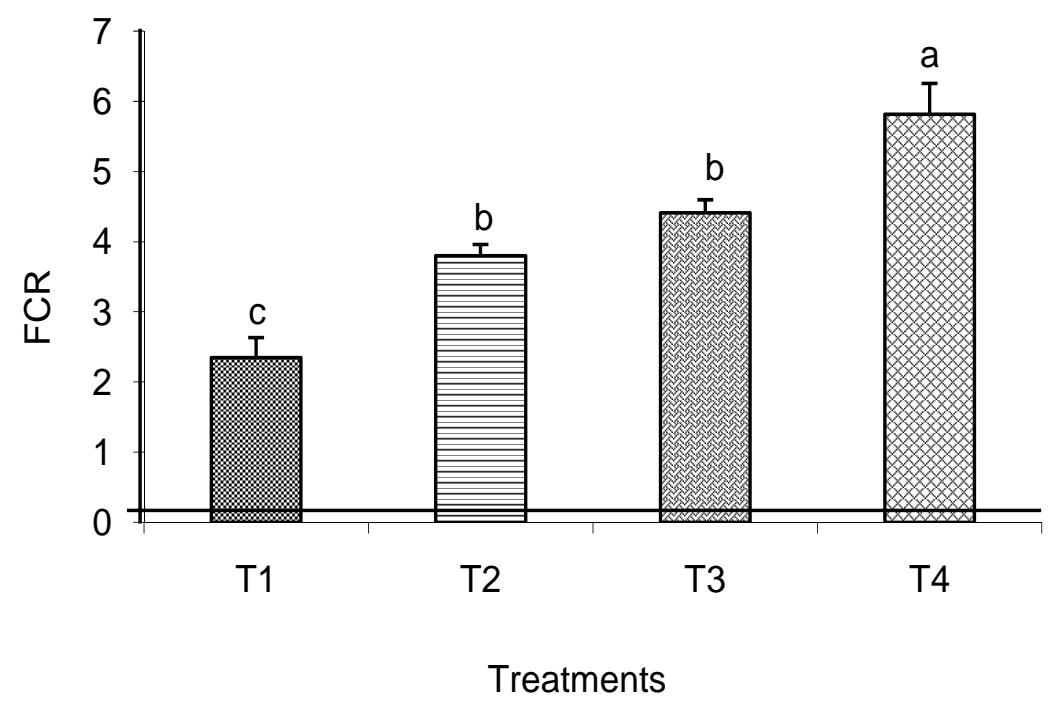

Fig. 7. Comparison of food conversion ratio (FCR) of $O$. niloticus fry fed different protein containing diets during the first experiment where $\mathrm{T}_{1}=35.95 \%, \mathrm{~T}_{2}=40.43 \%, \mathrm{~T}_{3}=45.61 \%$ and $\mathrm{T}_{4}=50.85 \%$

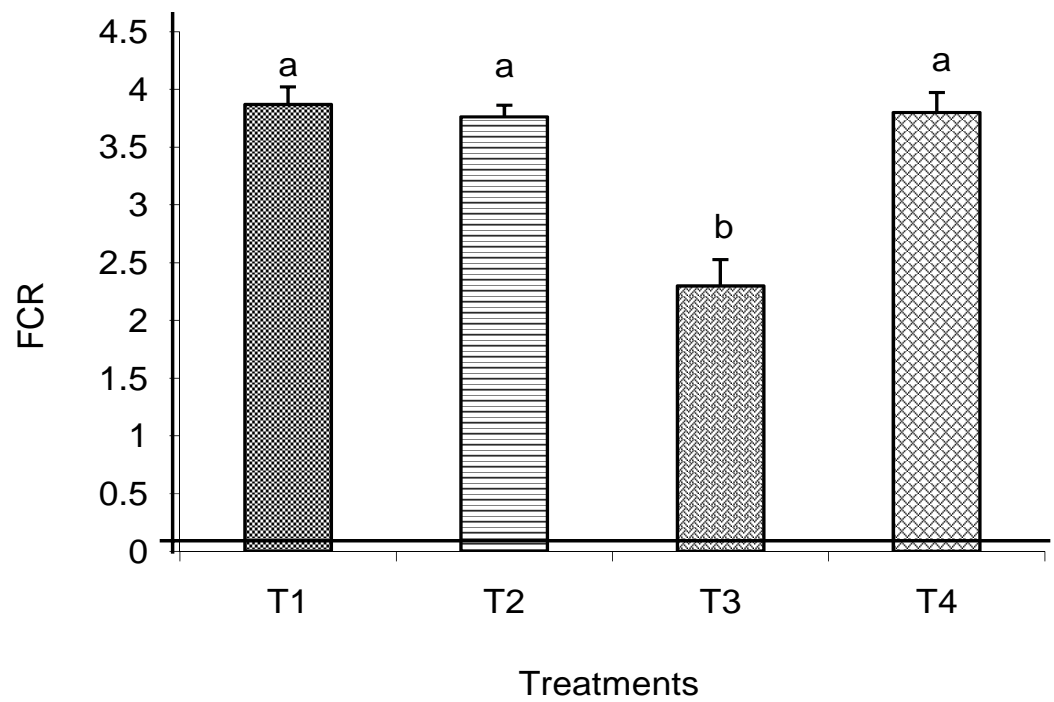

Fig. 8. Comparison of mean food conversion ratio (FCR) of $O$. niloticus fry fed different protein containing diets during the second experiment where $\mathrm{T}_{1}=30.12 \%, \mathrm{~T}_{2}=33.42 \%, \mathrm{~T}_{3}=36.19 \%$ and $\mathrm{T}_{4}=39.01 \%$

The protein efficiency ratio (PER) was within 0.35 to 1.21 in experiment 1 and 0.68 to 1.23 in experiment 2. Significantly $(P<0.05)$ higher PER was found in treatment $T_{1}$ and treatment $T_{3}$ of the first and second experiment respectively (Fig. 9 and 10). Bahnasawy (2009) found PER value 1.98 at 35\% protein for red tilapia fry.

The survival rate of $O$. niloticus fry under different treatments ranged from 88 to $93 \%$ in both the experiments. Significantly $(P<0.05)$ higher survival rate $(\%)$ was recorded in case of $T_{1}$ for the first and $T_{3}$ for the second experiment (Fig. 11 and 12). Sultana et al. (1997) obtained survival rate $95.75 \%$ of GIFT strain of Nile tilapia in nursery system. Survival rate more than $80 \%$ is excellent in nursery operation. Therefore from the findings it can be suggested that fry feed containing $36 \%$ protein is suitable for tilapia fry rearing. 


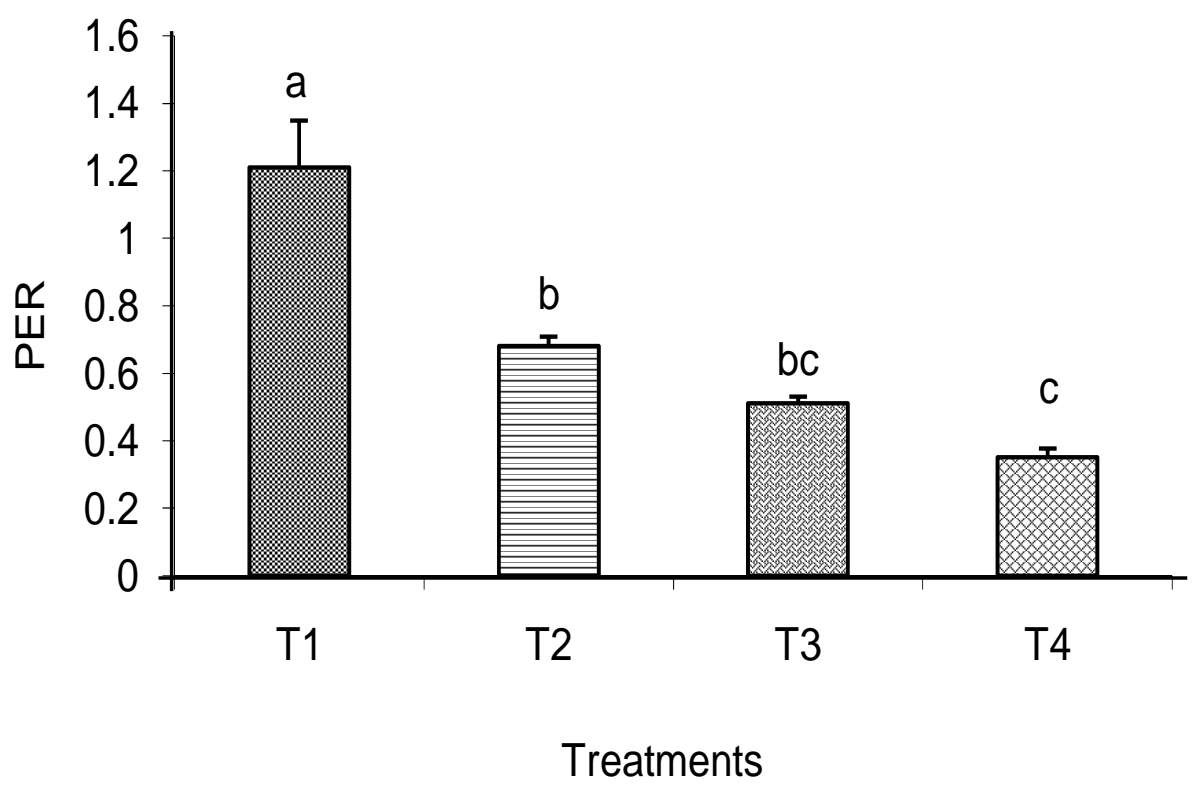

Fig. 9. Comparison of protein efficiency ratio (PER) of $O$. niloticus fry fed different protein containing diets during the first experiment where $\mathrm{T}_{1}=35.95 \%, \mathrm{~T}_{2}=40.43 \%, \mathrm{~T}_{3}=45.61 \%$ and $\mathrm{T}_{4}=50.85 \%$

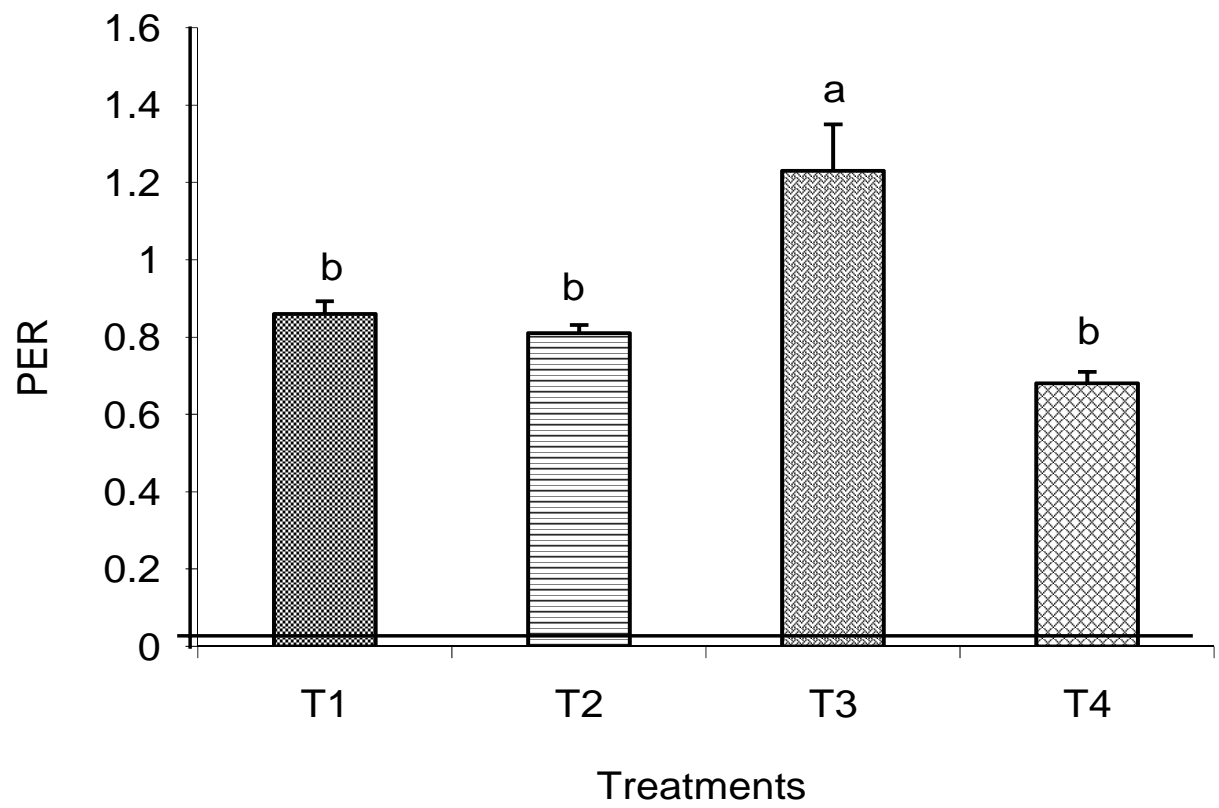

Fig. 10. Comparison of mean protein efficiency ratio (PER) of $O$. niloticus fry fed different protein containing diets during the second experiment where $\mathrm{T}_{1}=30.12 \%, \mathrm{~T}_{2}=33.42 \%, \mathrm{~T}_{3}=36.19 \%$ and $\mathrm{T}_{4}=39.01 \%$. 


\section{Sumi et al.}

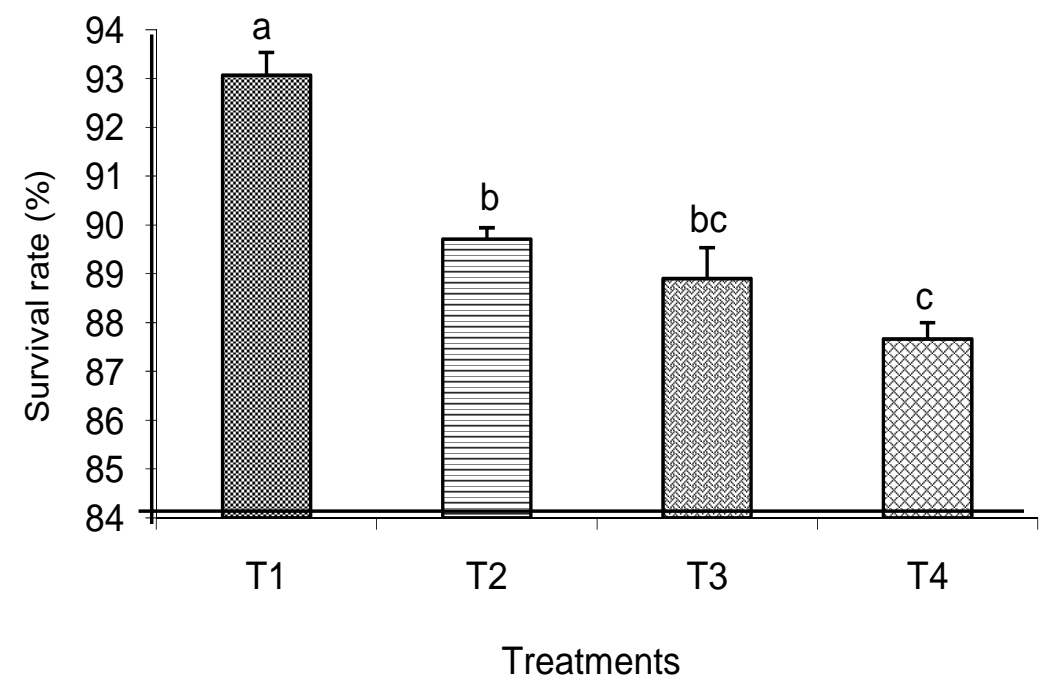

Fig. 11. Comparison of survival rate (\%) of $O$. niloticus fry fed different protein containing diets during the first experiment where $\mathrm{T}_{1}=35.95 \%, \mathrm{~T}_{2}=40.43 \%, \mathrm{~T}_{3}=45.61 \%$ and $\mathrm{T}_{4}=50.85 \%$.

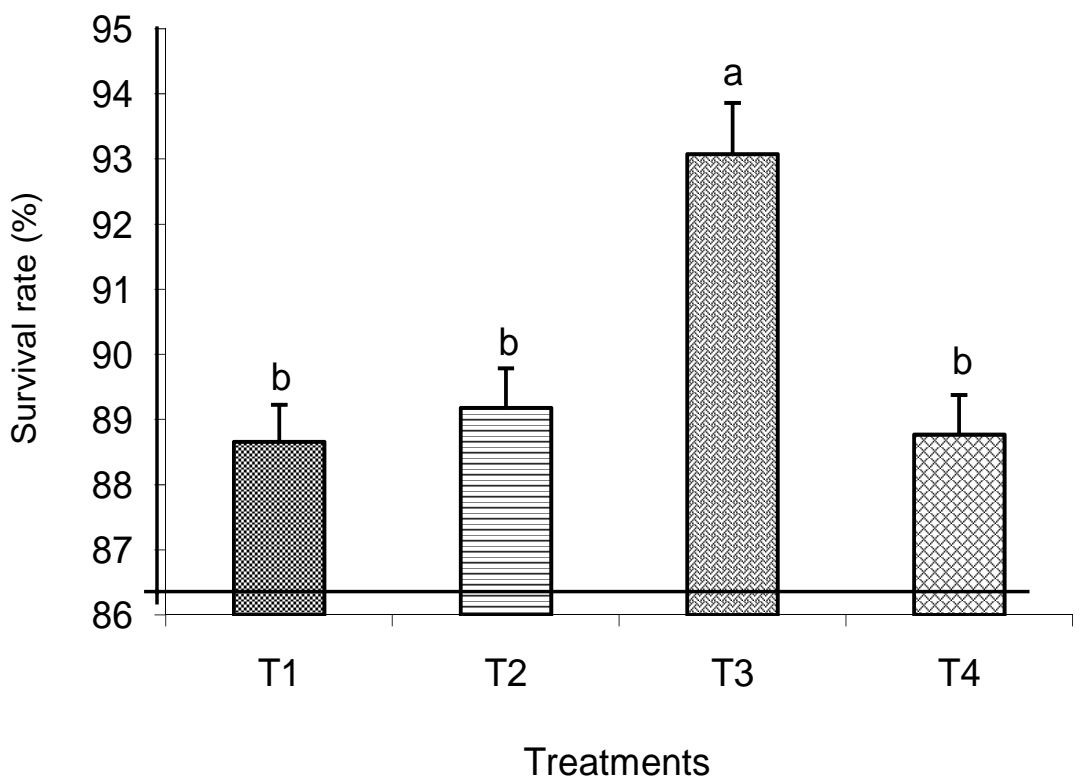

Fig. 12. Comparison of mean survival rate (\%) of $O$. niloticus fry fed different protein containing diets during the second experiment where $\mathrm{T}_{1}=30.12 \%, \mathrm{~T}_{2}=33.42 \%, \mathrm{~T}_{3}=36.19 \%$ and $\mathrm{T}_{4}=39.01 \%$.

Dietary protein level significantly influenced the growth of tilapia fry and the best results were obtained with a dietary protein level of $35.95 \%$ in the first experiment and $36.19 \%$ in the second experiment in respect of weight gain, SGR, FCR, PER as well as survival. So diet containing approximately $36 \%$ protein might be acceptable protein percentage for production of $O$. niloticus fry. Most of the hatchery owners use $40 \%$ protein diet and spend extra money for no use. If farmers use $36 \%$ protein that has been found suitable in the present two experiments conducted in consecutive years 2010 and 2011 instead of arbitrarily fixed $40 \%$ protein then it will be more economic for them. Thus, the feed containing $36 \%$ protein could be highly recommended for the production of tilapia fry. Further research can be carried out with $36 \%$ protein diet where protein source can be switched from fish meal to other cheaper ingredients still good enough to perform good growth and survival to reduce the fry production cost. 


\section{References}

AOAC. 2000. Official methods of Analysis. $17^{\text {th }}$ edn. Association of Official Analytical Chemist, Washington DC. 2200 pp.

Bahnasawy, M.H. 2009. Effect of Dietary Protein Levels on Growth Performance and Body Composition of Monosex Nile Tilapia, Oreochromis niloticus L. Reared in Fertilized Tanks. Pakistan J. Nutr., 8: 674-678.

Balarin, J.D. and Haller, R.D. 1982. The intensive culture of tilapia in tanks, raceways and cages. In J.F. Muir and R.J. Roberts, ed. Recent Advances in Aquaculture, Corm Helm, London. pp. 265-356.

Boyd, C.E. 1982. Water Quality Management for Pond Fish Culture. Elsevier Scientific Publishing Company, Amsterdam, Oxford, New York, 318 pp.

Brown, M.E. 1957. Experimental studies on growth. In M.E. Brown, ed. The Physiology of Fishes, Academic Press. New York, 1:361-400.

DoF. 1996. Matsha Pakkah Shankalan. Directorate of Fisheries, Ministry of Fisheries and Livestock, Government of the People's Republic of Bangladesh, Dhaka, Bangladesh. 81 pp.

El-Sayed, A.F.M. and Teshima, S. 1991. Tilapia nutrition in aquaculture. Rev. Aquat. Sci., 5(3-4): 247-265.

Hossain, M.A., Roy, R., Rahmatullah, S.M. and Kohinoor, A.H.M. 2004. Effect of stocking density on the growth and survival of GIFT tilapia, (Oreochromis niloticus) fed on formulated diet. J. Agric. Rural Dev., 2(1): 127-133.

Hussain, M.G., Kohinoor, A.H.M. and Islam, M.S. 2011. BFRI evolved improved fish variety and their dissemination strategy. In Jatiya Matsha Shaptaha Shankalan. Department of Fisheries, Ministry of Fisheries and Livestock, Government of the People's Republic of Bangladesh, Dhaka, Bangladesh. pp. 21-23.

Jauncey, K. and Ross, B. 1982. A guide to tilapia feed and feeding. University of Stirling, Scotland, UK. $111 \mathrm{pp.}$

Pillay, T.V.R. 1990. Aquaculture: Principles and practices. Fishing News Book. Blackwell Scientific Publications, Ltd., Oxford, UK. 575 pp.

Popma, T.J., and Lovshin, L.L. 1995. Worldwide Prospects for Commercial Production of Tilapia. International Center for Aquaculture and Aquatic Environments Department of Fisheries and Allied Aquacultures, Auburn University, Alabama. pp. 26-27.

Rahman, M.S. 1992. Water quality management in aquaculture. BRAC Prokashana, Mohakhali, Dhaka, Bangladesh. 84 pp.

Santiago, C.B., Banes-Aldaba, M. and Laron, M.A. 1982. Dietary crude protein requirement of Tilapia nilotica fry. Kalikasan Philipp. J. Biol., 11: 255-265.

Sultana, R., Kohinoor, A.H.M., Islam, M.M.S., Mazid, M.A. and Hussain, M.G. 1997. Comparative studies on growth of fry of GIFT and existing strains of Nile tilapia (Oreochromis niloticus L.). Bangladesh J. Fish. Res., 1(1): 25-30.

Wilson, R.P. 1989. Protein and amino acid requirements of fishes. In S. Shiau, ed. Progress in Fish Nutrition, National Taiwan Ocean University, Keelung, Taiwan. pp. 51-76.

Zar, J.H. 2010. Biostatistical analysis. 5th ed. Prentice Hall inc., New Jersey. 944 pp. 